\title{
A Novel Validated Stability-Indicating RP-HPLC Method for the Determination of Exemestane (Steroidal Aromatase Inhibitor)
}

\author{
Mathrusri Annapurna Mukthinuthalapati ${ }^{\star}$ and Venkatesh Bukkapatnam
}

Department of Pharmaceutical Analysis \& Quality Assurance, GITAM Institute of Pharmacy, GITAM University, Visakhapatnam, India

\begin{abstract}
Background: Exemestane is an active irreversible lipophilic steroidal aromatase inhibitor used to treat breast cancer in addition to surgery and/or radiation in post-menopausal women. It is a white to slightly yellow crystalline powder with a molecular weight of 296.41. Exemestane is freely soluble in $\mathrm{N}, \mathrm{N}$-dimethyl formamide, soluble in methanol, and practically insoluble in water. The present robust RP-HPLC method supports the quantitative analysis of Exemestane in pharmaceutical formulations and for carrying out the forced degradation studies.

Methods: A novel stability indicating liquid chromatographic method was developed for the determination of Exemestane using HPLC system of Shimadzu Model CBM-20A/20 Alite, equipped with SPD M20A prominence PDA and Zorbax SB C18 (150 mm $\times 4.6 \mathrm{~mm}$ i.d., $3.5 \mu \mathrm{m}$ particle size) column. A mixture of sodium acetate buffer and acetonitrile $(30: 70, \mathrm{v} / \mathrm{v})$ was used as a mobile phase with $1.0 \mathrm{ml} / \mathrm{min}$ flow rate and the method was validated as per ICH guidelines. Forced degradation studies were performed in different stress conditions such as acidic, basic, oxidation and thermal degradations.
\end{abstract}

Results: The proposed liquid chromatographic method has shown linearity over a concentration range $0.1-200$ $\mu \mathrm{g} / \mathrm{ml}$ with regression equation $\mathrm{y}=59411 \mathrm{x}-7316$ with correlation coefficient 0.999 . During the validation process i.e. the intra-day and inter-day precision studies, accuracy and robustness studies the method has shown an RSD of less than $2.0 \%$. Exemestane is found to be more stable during all the degradation studies because the percentage of degradation was reported to be less than 10 .

Conclusions: The proposed method was found to be precise, accurate and robust and it can be applied for the determination of Exemestane in any formulations.

Keywords: Exemestane; Liquid chromatography; Validation; Stability-indicating; ICH

\section{Introduction}

Exemestane is an orally active irreversible lipophilic steroidal aromatase inhibitor used for the therapy of metastatic postmenopausal breast cancer [1-3]. Exemestane (Figure 1) is chemically 6-methylenandrosta-1, 4-diene-3, 17- dione $\left(\mathrm{C}_{20} \mathrm{H}_{24} \mathrm{O}_{2} ; 296.403 \mathrm{~g} / \mathrm{mol}\right)$. The presence of 1,2-double bond in the ring of steroid molecule increased the aromatase in-activator affinity for the aromatase enzyme, which indirectly increased the therapeutic potency [4].

Exemestane has been determined by different analytical techniques such as LC-MS [5-9], GC-MS [10], LC-radio immunoassay [11], UVspectrophotometry [12], HPTLC [13] and UPLC [14].

Breda et al., developed a HPLC method in plasma by highperformance liquid chromatography with ultraviolet detection [15] whereas Burcin Yavuz et al. developed cyclodextrin complexes of

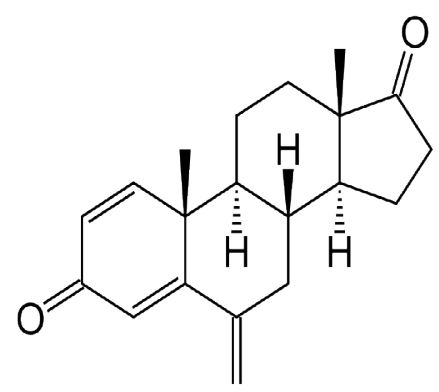

Figure 1: Chemical structure of Exemestane.
Exemestane to improve the solubility and here also the authors used HPLC method using acetonitrile and water mixture where the retention time was observed at more than 10 minutes [16] and [15-16] in pharmaceutical dosage forms and biological fluids. Uday et al. [17], Vijaya, Lakshmi et al. [18] proposed liquid chromatographic methods but they have not performed the stress degradation studies. Suresh Kumar et al. [19] have analysed Exemestane along with four impurities and the robustness was studied using Box-Behnken design.

Till now only two stability indicating HPLC methods are available in the literature in which Bharath et al. [20] developed a stability indicating method in which UV detector was used and the retention time of Exemestane was at around 7.0 minutes. Mathrusri Annapurna et al. [21] observed the elution of Exemestane at about 4.5 minutes using phosphate buffer and acetonitrile mixture. In the present study the authors have proposed a new simple, economical and robust stability indicating liquid chromatographic method (Isocratic mode) for the determination of Exemestane in pharmaceutical dosage forms (Tablets).

*Corresponding author: Mathrusri Annapurna M, Department of Pharmaceutical Analysis and Quality Assurance, GITAM Institute of Pharmacy, GITAM University, Visakhapatnam, India, Tel: 918912790101; E-mail: mathrusri2000@yahoo.com

Received April 28, 2015; Accepted November 17, 2015; Published November 24, 2015

Citation: Mukthinuthalapati MA, Bukkapatnam V (2015) A Novel Validated StabilityIndicating RP-HPLC Method for the Determination of Exemestane (Steroidal Aromatase Inhibitor). J Bioequiv Availab 7: 288-292. doi:10.4172/jbb.1000256

Copyright: (c) 2015 Mukthinuthalapati MA, et al. This is an open-access article distributed under the terms of the Creative Commons Attribution License, which permits unrestricted use, distribution, and reproduction in any medium, provided the original author and source are credited. 


\section{Materials and Methods}

\section{Chemicals and reagents}

Exemestane (purity 99\%) was supplied as a gift sample from Natco Pharma Ltd. (Hyderabad, India) and was used without further purification. Methanol (HPLC grade), Sodium hydroxide $(\mathrm{NaOH})$ and Hydrochloric acid $(\mathrm{HCl})$, orthophosphoric acid and Hydrogen peroxide $\left(\mathrm{H}_{2} \mathrm{O}_{2}\right)$ were purchased from Merck (India). All other chemicals were of analytical grade (Merck) and used as received.

Exemestane is available as tablets (Label claim $25 \mathrm{mg}$ ) with brand names $\mathrm{X}^{\prime} \mathrm{CEL}{ }^{\circ}$ (Celon Laboratories Ltd., India) and XTANE' (Natco Pharma Ltd, India) respectively.

\section{Instrumentation}

Chromatographic separation was performed on HPLC system of Shimadzu Model CBM-20A/20 Alite, equipped with SPD M20A prominence photodiode array detector by using Zorbax SB-C18 column $(150 \mathrm{~mm} \times 4.6 \mathrm{~mm}$ i.d., $3.5 \mu \mathrm{m}$ particle size $)$ as stationary phase for, maintained at $25^{\circ} \mathrm{C}$ and LC Solutions 1.25 software.

\section{Chromatographic conditions}

The mobile phase for the method was performed using Isocratic elution mode of sodium acetate buffer: acetonitrile $(30: 70, \mathrm{v} / \mathrm{v})$. The flow rate was set as $1.0 \mathrm{ml} / \mathrm{min}$. The UV detection was done at $254 \mathrm{~nm}$. $20 \mu \mathrm{L}$ of sample was injected into the HPLC system. The overall run time was $10 \mathrm{~min}$.

\section{Preparation of sodium acetate buffer $(\mathrm{pH} 4.0)$ solution}

The buffer solution was prepared by mixing $28.6 \mathrm{ml}$ of glacial acetic acid with $10 \mathrm{~mL}$ of $50 \% \mathrm{w} / \mathrm{v} \mathrm{NaOH}$ in to a $1000 \mathrm{ml}$ volumetric flask, dissolving and diluting to volume with HPLC grade water.

\section{Preparation of stock solution}

Stock solution was prepared by dissolving about $10 \mathrm{mg}$ of Exemestane in a $10 \mathrm{ml}$ volumetric flask with the mobile phase and further dilutions were made with mobile phase (sodium acetate buffer: acetonitrile $(30: 70, \mathrm{v} / \mathrm{v})$ and all the solutions were filtered through 0.45 $\mu \mathrm{m}$ membrane filter.

\section{Method validation}

The method was validated for linearity, limit of quantitation (LOQ), limit of detection (LOD), intra/inter-day precision, accuracy, robustness and specificity.

\section{Linearity}

A series of solutions $(0.1-200 \mu \mathrm{g} / \mathrm{ml})$ were made and $20 \mu \mathrm{L}$ of each was injected in to the HPLC system and the peak area of the chromatogram was noted. A graph was drawn by taking the concentration of the drug on the $\mathrm{x}$-axis and the corresponding peak area on the $\mathrm{y}$-axis.

\section{Limit of quantification (LOQ) and limit of detection (LOD)}

The limit of quantification (LOQ) and limit of detection (LOD) were calculated as described in International Conference on Harmonization guidelines Q2 (R1) [22].

\section{Precision study}

The intra-day precision and inter-day precision study was performed at three concentration levels $(20,50$ and $100 \mu \mathrm{g} / \mathrm{ml})$ on three different days i.e. day 1 , day 2 and day 3 respectively and the \% RSD was calculated.

\section{Accuracy study}

The accuracy of the method was evaluated at three levels (80, 100 and 120\%), and the percentage recoveries were calculated. Standard addition and recovery experiments were conducted for the quantification of Exemestane

\section{Robustness study}

The robustness of the assay method was performed to check the sensitivity of the method. In this small changes are made in the HPLC conditions which included wavelength detection range (252 and 256 $\mathrm{nm}$ ), percentage of acetonitrile in the mobile phase (28 and $72 \%$ ), flow rate $(0.9$ and $1.1 \mathrm{ml} / \mathrm{min})$ and $\mathrm{pH}$ (4.1 and 3.9). Robustness studies were done for the method with $100 \mu \mathrm{g} / \mathrm{ml}$ of Exemestane.

\section{Forced degradation studies/specificity}

Forced degradation studies were performed to evaluate specificity of the method $[23,24]$ and the forced degradation studies were performed by refluxing the Exemestane drug solution $(1 \mathrm{mg} / \mathrm{ml})$ with $0.1 \mathrm{~N} \mathrm{HCl}$ and $0.1 \mathrm{~N} \mathrm{NaOH}$ respectively for $30 \mathrm{~min}$ at $80^{\circ} \mathrm{C}$. The resulting solutions were then neutralized and diluted with mobile phase to give a final concentration of $50 \mu \mathrm{g} / \mathrm{ml}$. Oxidation was performed using $6 \% \mathrm{H}_{2} \mathrm{O}_{2}$ solution whereas thermal degradation was performed by exposing the drug solution to $80^{\circ} \mathrm{C}$ in a thermostat for 30 minutes. Photolysis was performed by exposing the drug solution to UV rays for about 6 hours in the UV chamber $(254 \mathrm{~nm})$.

\section{Assay of marketed formulations (Tablets)}

Commercially available marketed formulations (Tablets) were procured and finely powdered and powder equivalent to $10 \mathrm{mg}$ of Exemestane was transferred into a $10 \mathrm{ml}$ volumetric flask and acetonitrile was added to make up to volume. The contents were sonicated for 30 minutes and the solution was filtered. The filtrate was further diluted with mobile phase as per the requirement.

\section{Results and Discussion}

In the literature only two stability indicating liquid chromatographic methods were available and therefore there is need for the analytical techniques. A more economical and simple stability indicating RPHPLC method was proposed for the determination of Exemestane in presence of degradation products.

PDA detector is more advantageous rather than a UV detector in the chromatographic study. The peak area or peak height of the chromatogram can be measured at desired wavelength using PDA detector whereas UV detector can support only two different wavelengths. Also the PDA detector gives information about the purity index (peak purity and purity threshold) from which the impurity if any can be identified. The present proposed RP-HPLC method using PDA detector was compared with the previously published methods and summarized in Table 1.

\section{HPLC method development and optimization}

The drug samples were analyzed using different mobile phases with different $\mathrm{pH}$ and flow rates. Finally mobile consisting of sodium acetate: acetonitrile $(30: 70, \mathrm{v} / \mathrm{v})$ with flow rate $1.0 \mathrm{ml} / \mathrm{min}$ has given a sharp peak with all acceptable system suitability parameters with short 


\begin{tabular}{|c|c|c|c|}
\hline Method/Reagent & $\begin{array}{l}\text { Linearity } \\
(\mu \mathrm{g} / \mathrm{ml})\end{array}$ & Remarks & Ref. \\
\hline Acetonitrile-water & - & UPLC & 14 \\
\hline $\begin{array}{l}\text { Acetonitrile: } \mathrm{KH}_{2} \mathrm{PO}_{4} \\
(\mathrm{pH} 4.5)(35: 65, \mathrm{v} / \mathrm{v})\end{array}$ & $10-1000$ & $\begin{array}{l}\text { HPLC (Plasma) } \\
\text { UV detector }\end{array}$ & 15 \\
\hline $\begin{array}{l}\text { Acetonitrile: water } \\
\quad(44: 56, v / v)\end{array}$ & $2.5-50$ & HPLC & 16 \\
\hline Methanol: phosphate buffer & $20-100$ & $\begin{array}{c}\text { HPLC } \\
\text { PDA detector } \\
\text { (Gradient mode) }\end{array}$ & 17 \\
\hline $\begin{array}{l}\text { Water and methanol } \\
\quad(50: 50, \mathrm{v} / \mathrm{v})\end{array}$ & $25-150$ & HPLC & 18 \\
\hline Water: methanol & $25-150$ & $\begin{array}{l}\text { HPLC (Impurities) } \\
\text { Box-Behnken design }\end{array}$ & 19 \\
\hline $\begin{array}{l}\text { Acetonitrile-water } \\
\quad(60: 40, v / v)\end{array}$ & $6-14$ & $\begin{array}{c}\text { HPLC } \\
\text { UV detector } \\
\text { Very low linearity range }\end{array}$ & 20 \\
\hline $\begin{array}{l}\text { Phosphate buffer: acetonitrile } \\
(\mathrm{pH} 4.0)(40: 60, \mathrm{v} / \mathrm{v})\end{array}$ & $0.1-200$ & $\begin{array}{l}\text { Stability indicating HPLC } \\
\text { PDA detector }\end{array}$ & 21 \\
\hline $\begin{array}{c}\text { Sodium acetate buffer: } \\
\text { acetonitrile } \\
(\mathrm{pH} 4.0)(30: 70, \mathrm{v} / \mathrm{v})\end{array}$ & $0.1-200$ & $\begin{array}{l}\text { Stability indicating HPLC } \\
\text { PDA detector }\end{array}$ & $\begin{array}{l}\text { Present } \\
\text { work }\end{array}$ \\
\hline
\end{tabular}

Table 1: Comparison of proposed method with the previously published liquid chromatographic methods

retention time (UV detection at $247 \mathrm{~nm}$ ). The typical chromatogram so obtained for Exemestane was shown in Figure 2.

Beer-Lambert's law was obeyed over the concentration range:

$0.1-200 \mu \mathrm{g} / \mathrm{ml}$ (Table 2) with regression equation $\mathrm{y}=59411 \mathrm{x}+7315$

$(\mathrm{r} 2=0.999)$ (Figure 3)

The LOQ and LOD were determined based on the 10 and 3.3 times the standard deviation of the response, respectively, divided by the slope of the calibration curve. The LOQ is found to be $0.0906 \mu \mathrm{g} / \mathrm{ml}$ and the LOD is found to be $0.0299 \mu \mathrm{g} / \mathrm{ml}$.

The \% RSD in precision studies was found to be $0.29-0.67$ and 0.67 0.81 for intra-day and inter-day respectively indicating that the method is precise. The percentage recovery in accuracy studies was found to be 98.52-99.01\% with \% RSD 0.12-0.22 (less than 2.0) indicating that the method is accurate (Table 3 ).

In robustness studies, parameters such as flow rate, detection wavelength, $\mathrm{pH}$ and mobile composition were slightly altered and the percentage RSD was found to be $0.94-1.80$ indicating that the proposed method is robust (Table 4).

\section{Forced degradation Studies/Specificity}

Forced degradation studies were conducted for Exemestane with the optimized liquid chromatographic conditions and the typical chromatograms so obtained were shown in Figures 4A-4F. The PDA detector clearly represents the presence of degradants at a particular wavelength in the $3 \mathrm{D}$ chromatograms of Exemestane.

Exemestane has shown less than $10 \%$ degradation in all stressed conditions such as $3.61 \%$ (acidic), $2.80 \%$ (basic), $1.71 \%$ (oxidative), $6.88 \%$ (thermal) and $1.03 \%$ (photolytic) degradation (Table 5). During the oxidation degradation a sharp degradation peak was observed at 1.402 minutes. The pure drug peak obtained with theoretical plates more than 2000 and tailing factor less than 1.5 indicating that the proposed method is selective and specific. So the proposed stability indicating liquid chromatographic method can be applied successfully for the determination of Exemestane in pharmaceutical formulations.

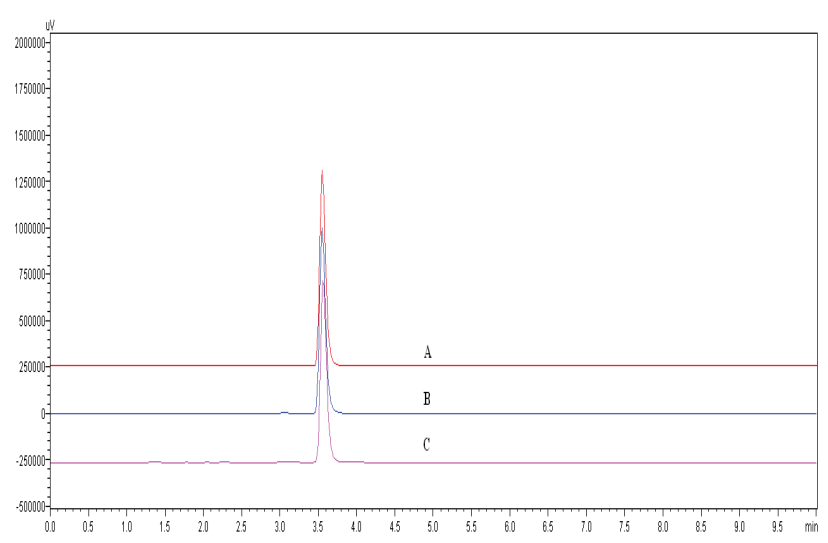

Figure 2: Representative Chromatograms of (A) Exemestane $(50 \mu \mathrm{g} / \mathrm{ml})$, (B) X'CEL ${ }^{\circledR}$ (Label claim: 25 mg) (C) XTANE $^{\circledR}$ (Label claim: $25 \mathrm{mg}$ )

\begin{tabular}{|c|c|c|}
\hline Conc. $(\boldsymbol{\mu g} / \mathbf{m l})$ & *Mean Peak Area \pm SD & RSD (\%) \\
\hline 0.1 & $6097 \pm 15.85$ & 0.26 \\
\hline 1 & $58790 \pm 199.89$ & 0.34 \\
\hline 5 & $295544 \pm 1182.18$ & 0.40 \\
\hline 10 & $611409 \pm 3913.02$ & 0.64 \\
\hline 20 & $1240314 \pm 4341.10$ & 0.35 \\
\hline 50 & $3025873 \pm 3328.46$ & 0.11 \\
\hline 100 & $5935485 \pm 17212.91$ & 0.29 \\
\hline 150 & $8725436 \pm 32284.11$ & 0.37 \\
\hline 200 & $12024332 \pm 73348.43$ & 0.61 \\
\hline
\end{tabular}

"Mean of three replicates

Table 2: Linearity of Exemestane.

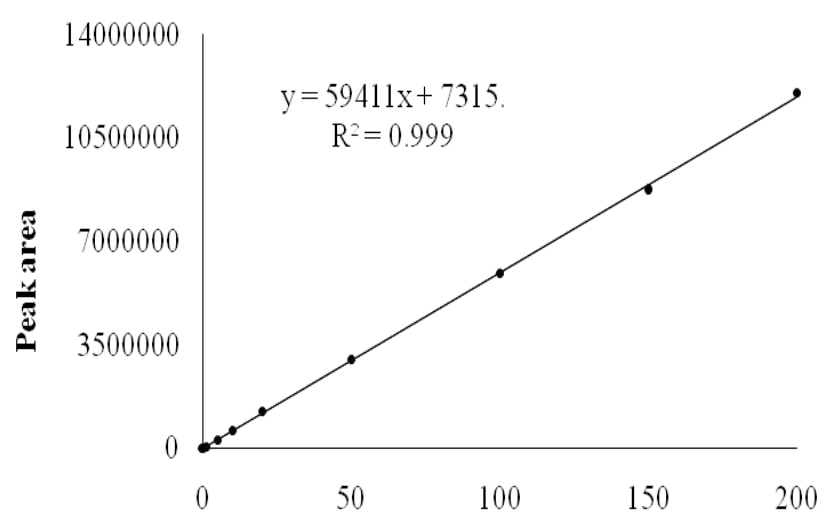

Conc. $(\mu \mathrm{g} / \mathrm{ml})$

Figure 3: Calibration curve of Exemestane

Application of the proposed method for the analysis of available formulations in the pharmacy store (Tablets)

The proposed method was applied to the determination of Exemestane tablets and the assay was calculated as 94.11-96.13\% (Table 6) and no interference was observed with the excipients (Figure 2B-2C).

\section{Conclusion}

The developed stability-indicating and RP-HPLC method is 
Citation: Mukthinuthalapati MA, Bukkapatnam V (2015) A Novel Validated Stability-Indicating RP-HPLC Method for the Determination of Exemestane (Steroidal Aromatase Inhibitor). J Bioequiv Availab 7: 288-292. doi:10.4172/jbb.1000256

\begin{tabular}{|c|c|c|c|c|c|c|c|}
\hline \multirow{3}{*}{$\begin{array}{l}\text { Conc. } \\
(\mu \mathrm{g} / \mathrm{ml})\end{array}$} & Intra-day precision & \multicolumn{2}{|c|}{ Inter-day precision } & \multirow[t]{2}{*}{ Parameter } & \multirow[t]{2}{*}{ Condition } & \multirow{2}{*}{$\begin{array}{c}{ }^{*} \text { Mean } \\
\text { peak area }\end{array}$} & \multirow{2}{*}{$\begin{array}{c}\text { *Mean peak area } \pm \text { SD } \\
(\% \text { RSD })\end{array}$} \\
\hline & \multirow{2}{*}{$\begin{array}{c}\text { *Mean peak area } \pm \text { SD } \\
(\% \text { RSD })\end{array}$} & \multirow{2}{*}{\multicolumn{2}{|c|}{$\begin{array}{c}\text { *Mean peak area } \pm \text { SD } \\
(\% R S D)\end{array}$}} & & & & \\
\hline & & & & \multirow{3}{*}{$\begin{array}{c}\text { Flow rate } \\
( \pm 0.1 \mathrm{ml} / \mathrm{min})\end{array}$} & 0.9 & 5824121 & \multirow{3}{*}{$\begin{array}{c}5892413.33 \pm 59812.60 \\
(1.02)\end{array}$} \\
\hline 20 & $1244826.33 \pm 8375.58$ & \multirow{2}{*}{\multicolumn{2}{|c|}{$1250654.33 \pm 9500.35(0.76)$}} & & 1.0 & 5935485 & \\
\hline & $\frac{(0.6 \%)}{(5)}$ & & & & 1.1 & 5917634 & \\
\hline 50 & $\begin{array}{c}3043333.00 \pm 8686.59 \\
(0.29)\end{array}$ & \multicolumn{2}{|c|}{$3000259.00 \pm 24281.95(0.81)$} & \multirow{3}{*}{$\begin{array}{l}\text { Detection wavelength } \\
\qquad( \pm 2 \mathrm{~nm})\end{array}$} & 252 & 5942156 & \multirow{3}{*}{$\begin{array}{c}5971042.00 \pm 55908.86 \\
(0.94)\end{array}$} \\
\hline 100 & $5878355.33 \pm 19598.07$ & \multirow{2}{*}{\multicolumn{2}{|c|}{$5838815.00 \pm 39056.33(0.67)$}} & & 254 & 5935485 & \\
\hline & $(0.33)$ & & & & 256 & 6035485 & \\
\hline \multicolumn{4}{|c|}{ Accuracy } & \multirow{3}{*}{$\begin{array}{l}\text { Mobile phase composition } \\
\text { phosphate buffer: acetonitrile } \\
( \pm 2 \%, v / v)\end{array}$} & $28: 72$ & 6014897 & \multirow{3}{*}{$\begin{array}{c}5924915.33 \pm 95705.25 \\
(1.62)\end{array}$} \\
\hline \multirow{2}{*}{$\begin{array}{l}\text { Conc. } \\
(\mu \mathrm{g} / \mathrm{ml})\end{array}$} & ${ }^{*}$ Mean peak area \pm SD & \multirow{2}{*}{$\begin{array}{l}\text { Drug Found } \\
\qquad(\mu \mathrm{g} / \mathrm{ml})\end{array}$} & \multirow{2}{*}{$\begin{array}{c}\text { * Recovery } \\
(\%)\end{array}$} & & $30: 70$ & 5935485 & \\
\hline & (\% RSD) & & & & $32: 68$ & 5824364 & \\
\hline \multirow[t]{2}{*}{18} & \multirow{2}{*}{$\begin{array}{c}1060838.67 \pm 1314.82 \\
(0.12)\end{array}$} & \multirow[t]{2}{*}{17.73} & \multirow[t]{2}{*}{98.52} & \multirow[t]{3}{*}{$\mathrm{pH}( \pm 0.1$ unit $)$} & 3.9 & 5837459 & \multirow{3}{*}{$\begin{array}{c}5832885.67 \pm 104960.75 \\
(1.80)\end{array}$} \\
\hline & & & & & 4.0 & 5935485 & \\
\hline 20 & $1183261.67 \pm 2533.63(0.21)$ & 19.79 & 98.97 & & 4.1 & 5725713 & \\
\hline 22 & $\begin{array}{c}1301425.67 \pm 2866.37 \\
(0.22)\end{array}$ & 21.78 & 99.01 & \multicolumn{4}{|l|}{ "Mean of three replicates } \\
\hline
\end{tabular}

"Mean of three replicates

Table 3: Precision and accuracy studies of Exemestane.

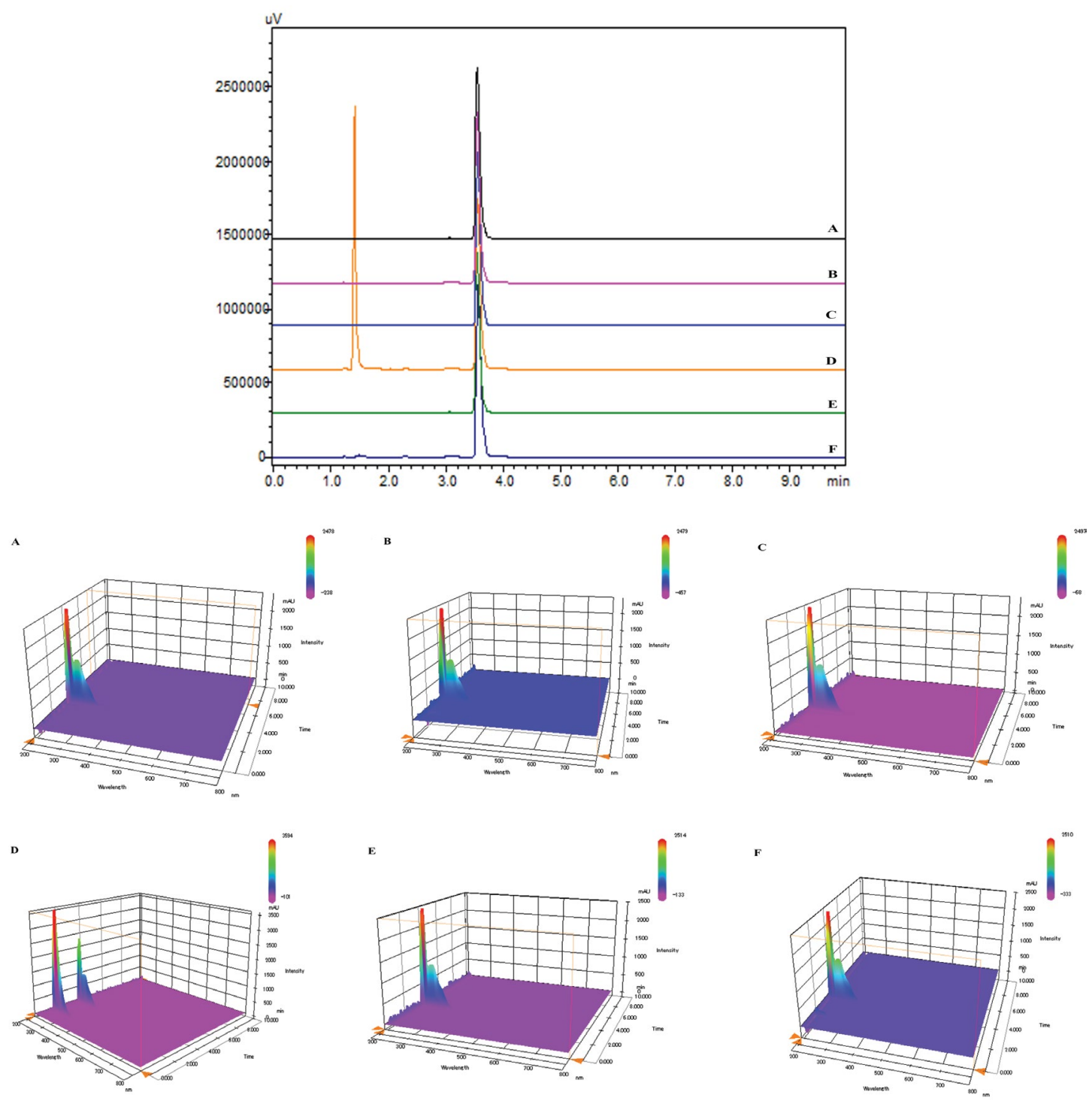

Figure 4: Representative Chromatograms of Exemestane $[A]$ acidic $[B]$, alkaline $[C]$, oxidative $[D]$, thermal $[E]$ and photolytic $[F]$ degradations 
Citation: Mukthinuthalapati MA, Bukkapatnam V (2015) A Novel Validated Stability-Indicating RP-HPLC Method for the Determination of Exemestane (Steroidal Aromatase Inhibitor). J Bioequiv Availab 7: 288-292. doi:10.4172/jbb.1000256

\section{Stress Conditions}

Standard Drug

Acidic degradation

Alkaline degradation

Oxidative degradation

Thermal degradation

Photolytic degradation

Mean of three replicates

\begin{tabular}{c} 
*Mean peak area \\
5935485 \\
\hline 5721046 \\
\hline 5769237 \\
\hline 5833858 \\
\hline 5526985 \\
\hline 5874137
\end{tabular}

\section{*Drug recovered (\%)}

100

96.39

97.20

98.29

93.12

98.97
*Drug decomposed (\%)

-
3.61
2.80
1.71
6.88
1.03

Theoretical Plates

7222.409

7575.085

7736.154

7882.941

7643.248

8022.939
Tailing factor

1.421

1.434

1.428

1.434

1.417

1.441

Table 5: Forced degradation studies of Exemestane.

Formulation
XTANE
X'CEL

"Mean of three replicates

Labeled claim (mg)
\[ \begin{array}{c}25 \\ 25\end{array} \]

Table 6: Analysis of Exemestane commercial formulation (Tablets).

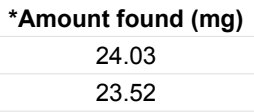

23.52
*Recovery (\%)

96.13

94.11 selective, precise and accurate. The stability studies of the drug show no degradation in any of the subjected conditions indicating that the drug molecule was very much stable in all the conditions. The developed method can be applied for the determination of Exemestane for marketed formulations.

\section{Acknowledgments and Conflict of Interest}

The authors are grateful to M/s GITAM University for providing necessary research facilities, NATCO Pharma Ltd. India) or providing the gift samples of Exemestane and University Grants Commission, New Delhi, India for their financial support. Authors have no conflict of interest.

\section{References}

1. Johannessen DC, Engan T, Di Salle E, Zurlo MG, Paolini J, et al. (1997) Endocrine and clinical effects of exemestane (PNU 155971), a novel steroidal aromatase inhibitor, in postmenopausal breast cancer patients: a phase I study. Clinical Cancer Research 3: 1101-1108.

2. Evans TR1, Di Salle E, Ornati G, Lassus M, Benedetti MS, et al. (1992) Phase I and endocrine study of exemestane (FCE 24304), a new aromatase inhibitor, in postmenopausal women. See comment in PubMed Commons below Cancer Res 52: 5933-5939.

3. Geisler J, King N, Anker G, Ornati G, Di Salle E, et al. (1998) In vivo inhibition of aromatization by exemestane, a novel irreversible aromatase inhibitor, in postmenopausal breast cancer patients. Clinical Cancer Research 4: 2089-2093.

4. Korzekwa KR, Trager WF, Smith SJ, Osawa Y, Gillette JR (1991) Theoretical studies on the mechanism of conversion of androgens to estrogens by aromatase. Biochemistry 30: 6155-6162.

5. Mareck U, Geyer H, Guddat S, Haenelt N, Koch A, et al. (2006) Identification of the aromatase inhibitors anastrozole and exemestane in human urine using liquid chromatography/tandem mass spectrometry. Rapid Commun Mass Spectrom 20: 1954-1962.

6. Cenacchi V, BarattÃ" S, Cicioni P, Frigerio E, Long J, et al. (2000) LC-MSMS determination of exemestane in human plasma with heated nebulizer interface following solid-phase extraction in the 96 well plate format. J Pharm Biomed Anal 22: 451-460.

7. Allievi C, Zugnoni P, Benedetti MS, Dostert P (1995) Determination of plasma levels of exemestane (FCE 24304), a new irreversible aromatase inhibitor, using liquid chromatography/ thermospray mass spectrometry. Journal of Mass Spectrometry 30: 693-697.

8. Ksyciß̊,ska H, BuÅı-KwaÅınik K, Szlagowska A, Rudzki PJ (2011) Development and validation of a sensitive liquid chromatography/tandem mass spectrometry method for the determination of exemestane in human plasma. J Chromatogr B Analyt Technol Biomed Life Sci 879: 1905-1910.

9. Cavalcanti GA, Garrido BC, Leal FD, Padilha MC, Mazzarino M, et al. (2011) Analysis of exemestane and 17 $\beta$-hydroxyexemestane in human urine by gas chromatography/mass spectrometry: development and validation of a method using MO-TMS derivatives. Rapid Communications in Mass Spectrometry 24: 3297-3302.

10. de Albuquerque Cavalcanti G, Carius Garrido B, Dias Leal F, Costa
Padilha M, Mazzarino M, et al. (2011) Detection of new exemestane metabolites by liquid chromatography interfaced to electrospray-tandem mass spectrometry. J Steroid Biochem Mol Biol 127: 248-254.

11. Cavalcanti Gde A, Garrido BC, Leal FD, Padilha MC, de la Torre X, et al. (2011) Detection of new urinary exemestane metabolites by gas chromatography coupled to mass spectrometry. Steroids 76 : 1010-1015.

12. Persiani S, Broutin F, Cicioni $P$, Stefanini $P$, Strolin Benedetti $M$ (1996) Determination of the new aromatase inhibitor exemestane in biological fluids by automated high-performance liquid chromatography followed by radioimmunoassay. Journal of Pharmaceutical sciences 4: 331-340.

13. Angalaparameswari $\mathrm{S}$, Thiruvengadarajan VS, Amruth Kumar $\mathrm{N}$ Kutumbarao M, Ramkanth S, et al. (2012) Analytical Method Development and Validation of Exemestane Tablet by UV Spectrophotometry. E- Journal of Chemistry 9: 2068-2073

14. Mane MB, Sangshetti JN, Wavhal PJ, Wakte PS, Shinde DB (2010) Determination of Exemestane in bulk and pharmaceutical dosage form by HPTLC. Arabian Journal of Chemistry 2: 1016-1024.

15. Reddy MM, Reddy KH, Ramkumar D, Reddy MU, Varaprasad B (2011) A novel high resolution RP-UPLC method for the quantitative determination of exemestane and its related compounds. Journal of Pharmacy Research 4: 546548.

16. Breda M, Pianezzola E, Benedetti MS (1993) Determination of exemestane, a new aromatase inhibitor, in plasma by high-performance liquid chromatography with ultraviolet detection. J Chromatogr 620: 225-231.

17. Yavuz B, Bilensoy E, Sumnu M (2007) Analytical Method Validation for HPLC Assay of Oral Anticancer Drug Exemestane. FABAD J Pharm Sci 32: 15-22.

18. Kumar UK, Vinatha B, Sunitha P, Sushma GS (2012) Method Development and Method Validation of Exemestane in Bulk and Pharmaceutical Dosage form by RP-HPLC Technique. Journal of Scientific Research in Pharmacy 1: 115-117.

19. Lakshmi VM, Seshagiri Rao JVLN, Rao LA (2010) RP-HPLC Estimation of Exemestane in Tablet Dosage Form. Asian Journal of Chemistry 22: 6911-6914.

20. Suresh Kumar R, Narasimha Naidu M, Srinivasulu K, Raja Sekhar K, Veerender M, et al. (2008) Development and validation of a stability indicating LC method for the assay and related substances determination of Exemestane, an aromatase inhibitor. Journal of Pharm Biomed Anal 50: 746-752.

21. Konda B, Tiwari RN, Fegade H (2011) Development and Validation of Stability Indicating Method for the Determination of Exemestane by Reverse Phase High Performance Liquid Chromatography. J Chromatogr Sci 49: 634-639.

22. Mathrusri Annapurna M, Swati B, Naga Ramya D, Pramadvara K, Sri Ram A, et al. (2014) A Validated Stability-Indicating Liquid Chromatographic Method for the Determination of Exemestane. Chemical science transactions 3: 961-968.

23. Alvarenga L, Ferreira D, Altekruse D, Menezes JC, Lochmann D (2008) Tablet identification using near-infrared spectroscopy (NIRS) for pharmaceutical quality control. J Pharm Biomed Anal 48: 62-69.

24. Food and Drug Administration, HHS (2003) International Conference on Harmonisation; Stability Data Package for Registration Applications in Climatic Zones III and IV; Stability Testing of New Drug Substances and Products; availability. Notice. Fed Regist 68: 65717-65718. 